\title{
Sources of Fiscal Risks and their Role in Shaping the Debt Load of the Russian Regions
}

Edelev D.A.

Moscow state university of food productions, Russia, 125080, Moskow, Volokolamskoye h., 11

Email: edelev@mgupp.ru

Tatuev A.A.

Kabardino-Balkarian state University named after H.M. Berbekov, Russia, 360004

Kabardino-Balkarian Republic, Nalchik, Chernyshevskogo st, 173

Email: arsen.tatuev@mail.ru

Lyapuntsova E.V.

Moscow state university of food productions, Russia, 125080, Moskow, Volokolamskoye h., 11 Email: liap-ev@mail.ru

Rokotyanskaya V.V.

Moscow state university of food productions, Russia, 125080, Moskow, Volokolamskoye h., 11 Email: rokotyanskay_V_V@mail.ru

Valuiskov N.V.

Branch Don State Technical University in Shachty, Rostov Region, Shachty, Shevchenko st., 147

Email: valuiskov58@mail.ru

Doi:10.5901/mjss.2015.v6n5p249

\section{Abstract}

To reveal the budgetary risks of the Russian regions caused by increase in debt loading and to offer the measures directed on elimination of an imbalance in economic development of subjects of federation. For the task solution applied methods of system approach to the study of fiscal risks, economic statistics (comparison, ranking, parallel rows). Sources of the budgetary risks of regions are revealed, the rating of appeal of debt tools is created, the most effective measures for decrease in debt loading of the Russian regions are defined. It is proved that in an unstable modern economic situation it is necessary to treat with bigger care increase in volume of debt obligations as the unreasoned debt policy stimulates inflationary processes, decrease in investment activity and by that makes negative impact on a level of development of real sector of economy (as at the national, and regional level) and by that to call into question GDP growth prospects with all from here the following adverse effects for economy of Russia.

Keywords: budgetary risks, debt loading, federal policy, regional policy, regional strategy, industry

\section{Introduction}

At the moment in the conditions of strengthening of unevenness of social and economic development of certain regions traditional forms and methods of support of development of economy become absolutely unpromising. Due to the increase in the budgetary risks caused by delay of growth of the Russian economy and geopolitical intensity big fears causes growth of debt load of subjects of federation. 


\section{Discussion}

\subsection{Sources of fiscal risks in Russian regions}

It is known that the budget process is inevitably associated with risk, being an activity that includes formation, consideration, approval and implementation of the federal budget, budgets of RF subjects, municipal budgets. Speaking about budget risks in general, we can say that they consist of the probability of a failure to implement measures of budget planning and budget policies in connection with irregularities in budgetary resources movement and/or their proportions. What are the main budget risks of Russian regions? Leaving aside the theorizing on what definition of the budget risk is more precise and on what grounds these risks can be classified, at the "bottom line" we can see that upon the occurrence of a risk situation in the budget process the following types of losses occur for federal subjects: economic, reputational and temporary, the causes and consequences of which are shown in Table 1.

Table 1. Analysis of the causes and consequences of budget risks*

\begin{tabular}{|c|c|c|}
\hline Types of Losses & Causes Occurances & Budget Consequences/Risks \\
\hline Economic Financial) & $\begin{array}{l}\text { growth of expenditure obligations } \\
\text { reduction of budget revenues }\end{array}$ & $\begin{array}{ll}- & \text { increase in budget deficit, } \\
- & \text { growth of debt liabilities, } \\
- & \text { inability to fully fund all expenditure obligations } \\
& \text { and functions of state power }\end{array}$ \\
\hline Reputational & $\begin{array}{l}\text { inefficient regional budget and fiscal } \\
\text { policy }\end{array}$ & $\begin{array}{ll}- & \text { loss of credibility from the public and businesses } \\
- & \text { unattractiveness of a region for investors } \\
- & \text { capital outflow to other areas }\end{array}$ \\
\hline Temporary & $\begin{array}{l}\text { inaccuracy of the original data, } \\
\text { incompetence of executives } \\
\text { poor planning of budget indicators }\end{array}$ & 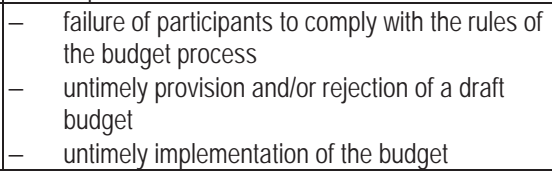 \\
\hline
\end{tabular}

*Source complied by the authors

According to the authors, among all budget risks the most serious ones are an increase in budget deficit and growth of debt liabilities. Consider these types of risks (as well as their causes) in more detail.

Almost a year ago experts warned that in the next three years, the budgets of all levels may face a shortfall in planned revenues and at the same time a significant increase in budget expenditures, including expenditures for implementation of the Presidential Decree dated May 7 2012, the "cost" is quite high (Fig. 1).

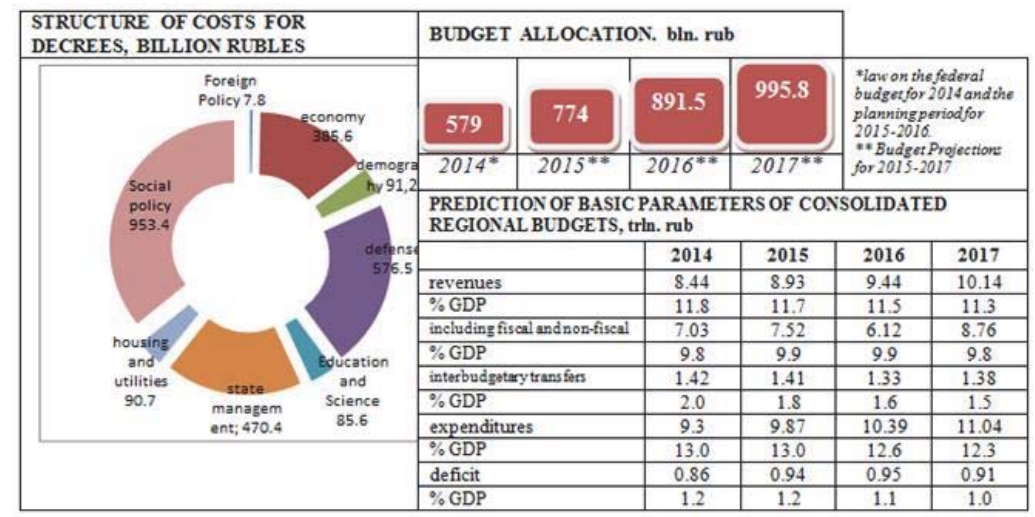

* Source: Russian Ministry of Finance website http://www.minfin.ru

Figure 1 - The cost of the May Presidential Decrees* 
Officials and experts are virtually unanimous; implementation of decrees can further aggravate the imbalance of regional budgets, especially in the face of declining revenues. It is estimated that consolidated revenues of all regions amounted to $12.2 \%$ of GDP, while in previous years this figure exceeded $13-14 \%$. We must say that mainly collectability of income tax decreased, in connection with which many regional budgets are in quite a difficult situation. Regional revenues are reduced not only because of the economic slowdown, some of the regions are affected due to a new procedure for calculating income tax by consolidated groups.

Naturally, all this leads to a fiscal gap in the Russian regions. It should be noted that in 2013 the gap between the growth rates of revenues and expenses was the most significant in the last ten years. This gap automatically leads to an increase in deficit.

In 2012 the overall deficit reached the level of 2009, but in 2013 - more than two-fold excess of these indicators was noted. For example, according to the official data, as of year-end of 2013 the number of regions, budgets of which were consolidated with a deficit in comparison with 2012 (81\% or 67 subjects) increased by $12 \%$ and amounted to 77 , while the deficit of consolidated budget increased by 2-3 times, and the amount of state and municipal debt increased by $27 \%$. According to senior Russian officials in 2014-2015 regional budget deficit will amount to $1 \%$ or more, i.e. about to 700-800 billion roubles.

With regard to the financing of the growing deficit, in 2013 in general in a number of regions the budget remnants were used as a relevant source (approximately 160 billion roubles). To some extent, this alowed "curbing" the pace of growth of the public debt. However, the reserves of the regional budgets are running low, and if the 2014 deficit will remain at the same level, the prospect of finding new reserves to cover the budget deficit looks rather illusive.

Russia's Ministry of Finance also warns of some unpleasant moments associated with the federal budget, which in the next three years could also face a shortfall in planned revenues from privatization and the failure of implementing borrowing programmes. Also it is necessary to admit that this pessimistic scenario, which seriously increases budget risks in the period ahead, is very likely, as this year the Ministry of Finance due to the deterioration of the situation on the debt market has refused from the programme of external borrowing in the amount of $\$ 7$ billion, in addition, internal borrowings have been significantly reduced as well. The planned privatization programme also experiences serious difficulties. Thus, shortfalls in projected revenues due to the difficult situation in the global economy are now more likely than ever. In view of the recent events, this threat is real enough. On this background Russian Ministry of Finance made a number of tax initiatives (increase in VAT, personal income tax, etc.), which, in the opinion of their authors, are able to balance regional budgets and eliminate the current budget gap.

\subsection{Debt problems of the Russian regions}

The regional policies are of particular concern, despite warnings of the federal government, the regions consistently continue to build up debts.

The expert community believes that the main reason for this behaviour is a habit to hope that in a critical situation the centre will come to help. The second reason is that the regions increase borrowing in order to fulfil the increased volume of obligations that became a heavy burden for regional budgets.

Why does the situation in the regions keep getting worse? We know that the 2008 crisis served as an impulse. The economic downturn led to a serious shortage of budget funds. As a result, in 2010, the regions received generous capital infusion to cover their budget deficits. At that moment, it seemed the best solution, as it was expected that after 3 years (i.e. in 2013), there will be a significant improvement in the economic situation and all of these credits will be repaid. Unfortunately, it was an illusion: 2013 came and we have moved up close to a dangerous point, because this year the Russian regions will have to repay more than a third (31\%) of accumulated debts, which is about $420.6 \mathrm{bln}$. rub.

Some experts fear that in the next two or three years, the debts of Russian regions can be increased by 2 times, and that this could be a straight path to bankruptcy. For example, according to the data of the international rating agency Standard \& Poors, which looks quite convincing, in 2 years the total regional debt will reach 3 trillion rub., and its growth will outstrip the rate of growth of the regional revenue by about a third.

Such predictions can not but cause concern and require a lot of attention to the problem of the public debt management, the research that many prominent scientists, economists have dedicated their work to for several decades (Barro, 1989; Cochrane, 2011; Groneck, 2010; Elmendorf \& Mankiw, 1999; Hanson, 2007; Keynes, 1936; Kutivadze, 2012; Modigliani, 1961; Moore \& Chrystol, 2006; Sutherland \& Hoeller, 2012)

The analysis of theoretical sources, addressing issues of public debt, leads to the conclusion that the instability of the current economic situation should make all countries be cautious of increasing debt liabilities (Anderson \& Anderson \& Velandia-Rubiano, 2010). 
However, many authors are turning their attention to the danger of the steady growth of a national debt (Checherita \& Rother, 2010; Siti \& Mohd \& Podivinsky, 2013), especially for emerging economies, as increased debt stimulates inflation processes, decline in investment activity and thus has a negative impact on the development of the real sector of the economy (both at the national and regional level), and thus jeopardizes the prospects for GDP growth, with all the adverse consequences for national economies (Cochrane, 2011; Gale \& Orszag, 2003; Kutivadze, 2012; Schclarek, 2005).

Let's try to apply to the figures and to compare the level of internal regional debt for the Russian regions. According to the Russian Ministry of Finance in 2013, the top ten "leaders of debt" includes the following 10 Russian regions with the highest debt burden. At first glance, it is a bit surprising that the "top ten" regions were so different in terms of economic development (Fig. 2). But if you ponder, everything becomes clear. Apart from the top three honourable places, which are predictably taken by Tatarstan, the Krasnodar and Moscow regions, other regions appeared in the top ten debtors list due to very logical reasons.

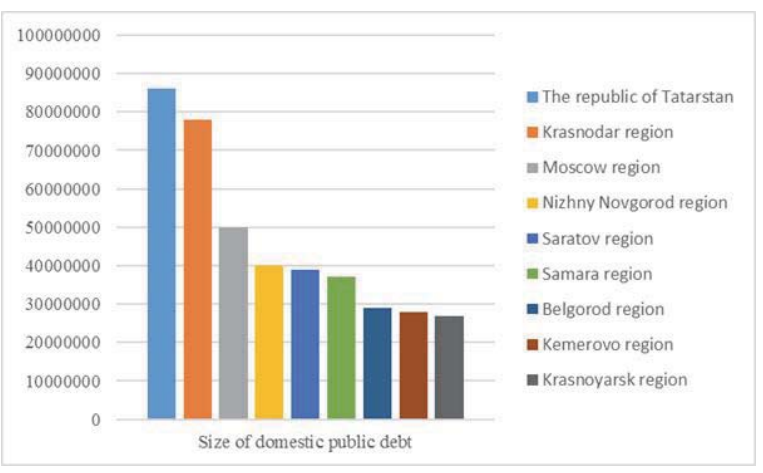

* Source: Russian Ministry of Finance website http://www.minfin.ru

Figure 2 - 10 Russian regions with the largest volume of domestic debt*

With a shortage of funds for the implementation of budget commitments, when $70 \%$ of all budget expenditures go to social sphere workers' salaries (education, health) according to different estimates, regions do not have any opportunity to make a "budget manoeuvre", i.e. engage in spending cuts. Regions with higher potential budget potential increase their debts with the implementation of major infrastructure projects which in their vast majority do not "fit" into original budgets.

In general, at the beginning of this year, the overall size of the public regional debt reached 1.35 billion roubles or approximately $25 \%$ of all regional revenues. How dangerous is this? If we analyse the amount of debt of similar EU budgets, these figures are not as high. At the same time, it is quite interesting to compare "debt leaders" the size of the public debt and GDP per capita with the size of the average salary in the regions (Figure 3).

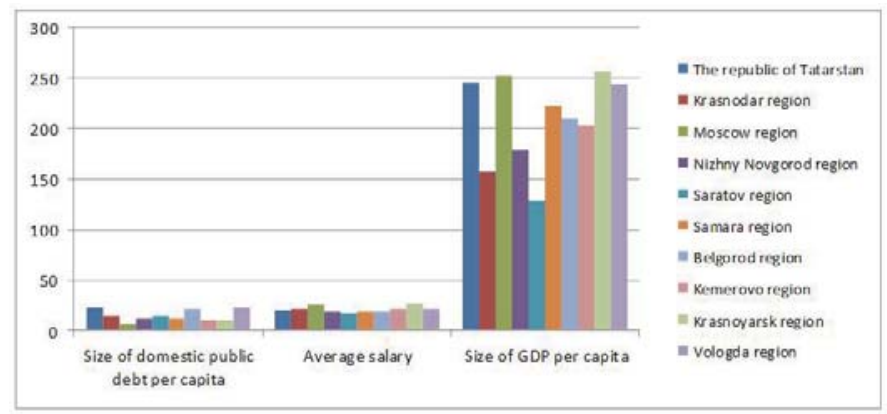

* Source: Russian Ministry of Finance website http://www.minfin.ru

Figure 3 - Comparison of regional leaders of the debt rating by three parameters* 
The diagram shows that if the average salary in these regions ranges from 26.5 (Krasnoyarsk region) to 16.9 (Saratov region) ths. rub., the differences in the size of the GRP and the national debt per capita are even more significant. It also should be noted that the Moscow, Krasnoyarsk and Kemerovo regions have a good position with fairly low levels of public debt per capita and some good values of the average salary. As for the Saratov region, its problems are mostly due to the fact that the region has received insufficient intergovernmental transfers.

At first glance, the situation does not look catastrophic. If so, then why is the expert community so concerned? The fact is that some of the debt leaders (for example, in the Belgorod and Saratov regions) the debts have already exceeded $80 \%$ of all budget revenues.

A more impressive picture can be seen by comparing these ten regions by two indicators: the size of the national debt per capita and the average salary (see. fig. 4).

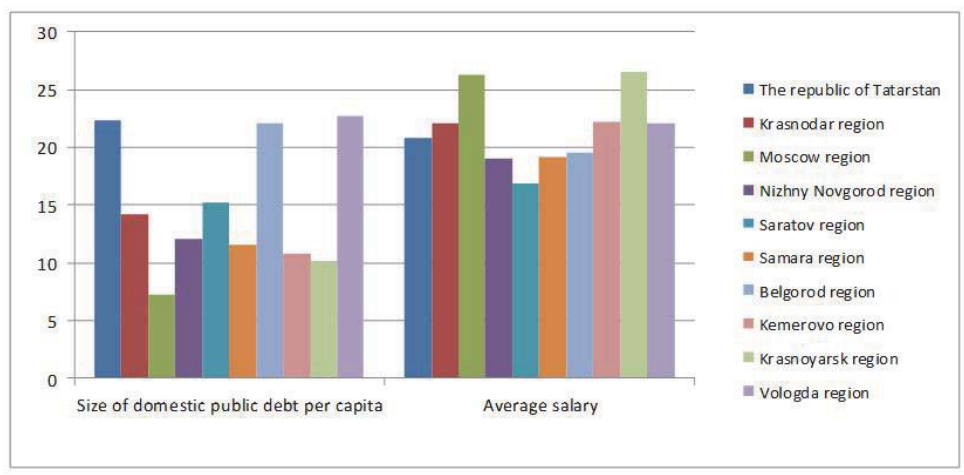

* Source: Russian Ministry of Finance website http://www.minfin.ru

Figure 4 - The differences in the average level of salary and the amount of domestic debt per capita in 10 regions with the highest level of domestic debt

If we compare the regions in terms of public debt per capita, we'll see that the three leaders are the Vologda region (22.7 ths.), the Republic of Tatarstan (22.3 ths. rub), and a bit unexpectedly, the Belgorod region takes the "honorary" third place with 22.1 ths. rub. Then the Saratov and the Krasnodar regions go far behind (15.2 and 14.2 ths. rub. respectively).

\subsection{Analysis of debt load of the Russian Federation subjects: the latest trends}

Russian and foreign experts have repeatedly warned that the buildup of government debt of the federation subjects can have very dangerous consequences, however at this point (autumn 2014), we must admit that the debt problems of Russian regions continue to cause serious concern.

The increase in the deficit of regional budgets led to the situation, when in 2013 the volume of public debt of 37 subjects of the Russian Federation (44.6\% of the total) exceeded 60\% of their own revenues (in 2012 - in 18 regions). At the same time, in seven RF subjects the public debt exceeded the amount of revenues (in 2012, there were only two of such subjects). The greatest excess of public debt over the amount of own revenues was registered in the Republic of Mordovia (172.1\%), and the Chukotka Autonomous District (123\%). Moreover, if the deficit begins to increase, the subjects of the Russian Federation will rapidly approach the critical level of public debt. 


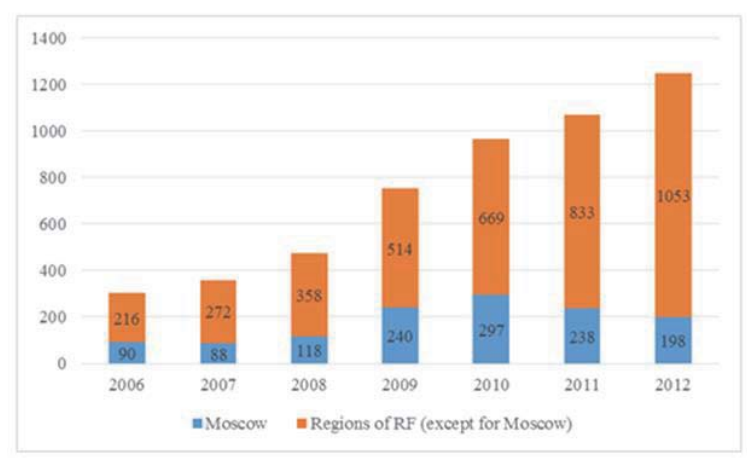

* Source: RF Treasury http://www.roskazna.rul

Figure 5 - Dynamics of debt burden of the Russian Federation subjects*

In other regions, the situation is also far from optimistic, as in the Belgorod region the amount of debt amounted to $110.3 \%$ of own revenues, the Republic of Ingushetia - 107.9\%, the Vologda region - 105.3\%, the Republic of North Ossetia-Alania - $103.2 \%$, the Saratov region $-102.3 \%$. In seven regions the debt to the state (again on the basis of budget implementation in 2013) was more than $90 \%$ of their own revenues: the Smolensk, Ryazan and Kostroma, Pskov regions - 97.3, 96.1, 96 and 92.8\%, respectively; the Republic of Mari El - 92.8\%, the Republic of Karelia - 90.1\%, the Krasnodar region $-90.4 \%$. Thus, we see that the total debt of the Russian regions is quite impressive.

At the same time, about two months ago the finance minister said that as of May 1 the debt of the regions fell by 41 billion roubles since the beginning of the year. However, it is not clear yet how stable this trend is, and therefore it is advisable to consider changes in the amount of domestic public debt of Russian regions, which entered the top ten of the debt leaders for the past year (see. Fig. 6).

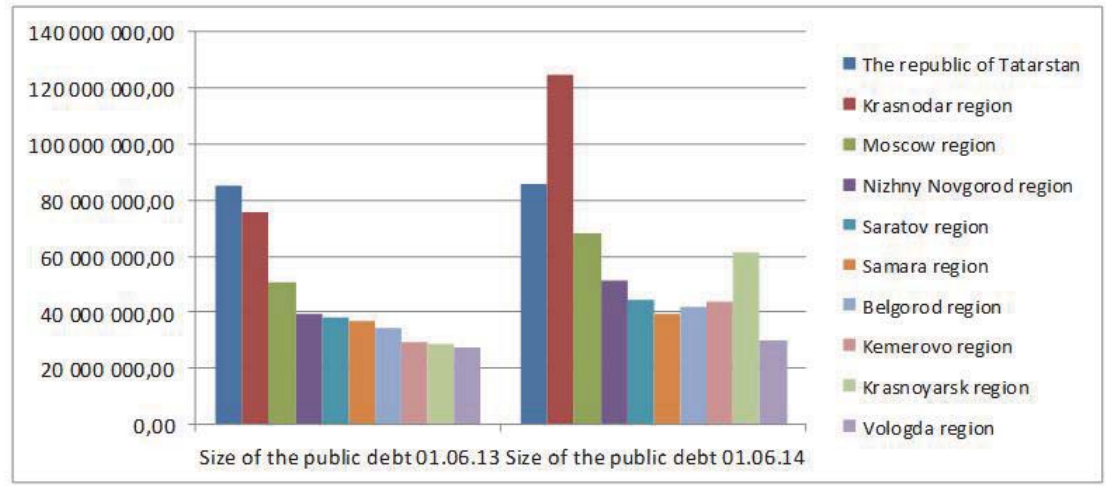

* Source: Russian Ministry of Finance website http://www.minfin.ru/ru/public_debt/subdbt/index.php)

Figure 6 - Changes in the volume of public debt of top ten debt leaders among Russian regions (excluding Moscow), ths. rub. *

As can be seen from the diagram, practically all regions (except for the Republic of Tatarstan, where the increase amounted to 442528.4 thousand) increased the volume of public debt significantly for the past year (from 01/06/13 till 06/01/14). In this regards, we especially should note the Krasnodar region (an increase of 1.6 times) and the Krasnoyarsk region (an increase of 2.1 times). And the size of the Krasnodar region national debt reached an astronomical mark and made $124,582,319.5$ ths. rub. Although in fairness it should be noted that the budgetary credits of the Krasnodar region and the Republic of Tatarstan issued in connection with the 2014 Olympic Games and the Universiade, were extended for 20 years. 
However, despite this, we confirmed our fear that the tendency to reduce the national debt will not be maintained, given that according to the Russian tradition, most of the costs carried are transferred over to the second half or the end of the year. It is easy to see that there is no reason to assume that according to the results 2014 it will be possible to reduce (or at least stabilize) the amount of public debt, and on the contrary, it will more likely continue its "sustainable" growth, particularly in view of the possible economic problems due to the deteriorating foreign policy situation due to the events in Ukraine. The situation with the public debt in a number of subjects can already be assessed as very critical.

According to the Russian Finance Ministry, it is partially the regions' fault in the growth of debt as well, as they regularly act in contravention of restrictions on their debt policy. On the other hand, the control measures are insufficient as well, for example, in reality the concept provisions, aimed at development and application of practical constraint measures regarding the budget process participants, are not fully implemented. Thus, the listed risks associated with the growth of the budget deficit and the public debt of the Russian Federation may require implementation of additional measures to minimize the negative effects of the unproductive regional policy. Perhaps this moment has already come, especially due to the fact that as of 01.05.14 the total amount of debt of the federal budget reached 1 trillion 686 billion roubles (according to other estimates, it has a;already exceeded 2 trillion roubles). However, the regions owe not only to the state. The growth of accumulated budget credits is of equal concern.

Thus, we see that the situation is indeed very serious. At the same time we can not but agree that the buildup of debt is rather a consequence, there are underlying problems that have been left beyond the scope of our discussion. But on the other hand, we see that the attempt to find a solution to the debt problems of the regions can be successful if we try to deal with it consistently. If we give up, it will be a complete dead end.

So, it is obvious that the debt problem is indeed very important for the majority of Russian regions. At the same time, in the study of this problem we should pay attention to the current structure of regional debt liabilities.

\subsection{The rating of attractiveness of debt instruments}

Analysis of the attractiveness of debt instruments showed that in 2008 the debt structure of Russian regions has undergone significant changes. The volume of budget credits grew almost by 5.5 times from 6.8 to $37.2 \%$, while the size of government guarantees reduced by more than 2 times (from 20.6 to 8.9\%), the same dynamic is typical for bank credits (decrease by almost 1.6 times - from 44.9 to 28.3\%). At the same time the share of bank credits keeps being stable. Let's try to understand, why is this happening?

It is logical that the regions are reluctant to take bank credits - the interest rate is too high. As for securities, this tool is unavailable because no one of our "top ten" regions has an appropriate credit rating and the price of taking such loan will be prohibitive. The tool of state guarantees became less popular due lack of investment attractiveness in most regions, but the attractiveness of budget credits grew "by leaps and bounds".

So the first place is taken by budget credits and for good reason. The impulse for this was the post-crisis year as well, as it was then when the possibility to obtain cheap borrowings allowed "keeping" and stabilizing the situation in the regions. Since then and so far, the regions are not willing to give up this tool and consistently increase the share of budget credits in the structure of their public debt. Unable to repay existing debts and turning to the federal centre for restructuring and prolongation, the regions continue to hope for new loan infusions from the federal government, which in turn can not continue to increase financial support to the subjects. The instability of the economic situation has led to the point when the federal centre begins to take serious measures to influence the regions-debtors.

In the structure of debt obligations of Russian subjects as of April 1, 2014 budget credits and loans, taken from other budgets of the budgetary system of the Russian Federation, accounted for $27.3 \%$, government securities $-25.6 \%$, credits from credit institutions, foreign and international financial institutions $-40 \%$, state guarantees $-7 \%$ and other liabilities $-0.1 \%$. During 2013 the share of expensive bank loans in the regions' debt increased from $32.6 \%$ to $39.8 \%$, debt servicing costs increased by $22.2 \%$. As of April 1, 2014 the regions owed banks the amount, estimated at 702.1 billion roubles. Growing debt load of RF subjects during stagnation of the Russian economy is of growing concern, including the Government of the Russian Federation.

At the same time, the situation in the sphere of bank loans is not very favourable as well, so the first quarter of the current year has been very difficult for the lending market of RF subjects, since there have been changes in the growth trend in this segment, which have been observed in the past few years, Again experts connect it with the increasing complexity of the geopolitical situation which has very negative impact on the stability of financial markets. They refer to the following factors as well: beginning of the federal contract system implementation and the freeze of pension savings, which significantly reduced the amount of financial resources that are traditionally invested in debt securities and also provide a basis for the purchase of RF subjects bonds. The total effect of these factors results in increased borrowing 
costs for Russian borrowers (borrowing costs for "long" government securities have already exceeded 9\%), due to the fact that the risks of investing in rouble instruments are estimated as high.

All this is happening against the background of decrease in the ratings prediction for a number of RF subjects Moscow, St. Petersburg, the Republic of Tatarstan, the Tyumen region and the Khanty-Mansiysk Autonomous Okrug. The issue of confidence in the major rating agencies (such as e.g. Fitch and Standard \& Poor's) may stay "open", but these predictions have a negative impact on the ability of regions to attract borrowed funds (and their cost), which also increases the cost risks.

This finding is also true with regard to credit risks of Russian regions; moreover, the pressure on their budgets continues to grow. In addition, there are no reasons to hope that in 2014-2015 visible positive changes will occur.

\subsection{Measures aimed at improving the situation. As regions will survive the next budget cycle?}

Meanwhile, Russia's Finance Ministry proposed a specific set of measures aimed at improving the balance of regional budgets. For example, in the coming years (and in particular in 2015-2017) changes in the budget legislation will be adopted, which will toughen the conditions for borrowings, the possibility of servicing and repaying of which is not determined by the amount of expected revenues. The Ministry of Finance also intends to gradually reduce the cost of servicing bank loans by partial replacement by budget credits from the federal budget as well. In this regard the activity of financial restructuring of the budgets of RF subjects will be also enhanced.

However, even if we see positive changes in the economy, under the influence of which the deficit of regional budgets begin to decline, it will still be higher than the federal budget deficit, i.e. regions will have to borrow. It is estimated that only due to increased salaries, the budgets expenses of RF subjects in 2014-2015 will grow by about $18 \%$ and to cover the deficit about 1.7 trillion and 1 trillion roubles annually in 2016-2018 must be found. It seems that the amount of financial assistance from the federal government will not allow the regions to carry it out, so the regions cannot go without additional federal support over the planned budget (80 billion roubles).

How do subjects suggest returning these debts? Recently, they got a hope to get cheap loans. We are talking about the intention of the Russian Finance Ministry to reduce the rate of budget credits for the regions to the symbolic one and allocate (in replacement of bank loans) an additional 100 billion roubles with a corresponding rate reduction from 2.75 to $1 \%$ per annum. Although against the background of the amount owed to the federal budget (1 trillion 686 billion roubles), the amount of additional budget lending does not look too impressive, since it is almost 17 times less.

At the same time a number of specialists consider that the extent of budget problem may be a little exaggerated, since not so much the volume of the national debt, but its structure and maturity are important. With this regard the German territories, some of which with the debts exceeding annual budget revenues by $200 \%$, is often cited. Why is it so? The fact is that their debts consist primarily of bonds with maturity terms of 30-50 years. However the same can't be said of the debts of Russian regions: most of them have more short terms, only public budget loans are the most longtermed ones. That's why though the volume of regional debts is rather small (if only compared to international practice), in circumstances where annually $50 \%$ of debt burden have to be refunded, there is a risk that the borrowing costs will rise, as well as a risk that debt payment peaks will coincide with some negative trends in revenues sphere. The more so because regions rely on such an unsustainable and massive source as profit taxes. It is natural that in the context of higher-than-anticipated growth of recurring expenses regions are still much dependent on federal transfers, while having fewer and fewer incentives for development and proficient debt management. All these factors impoverish budget of Russian regions and therefore some prompt recovery measures should be taken.

It should be stated that nowadays in circumstances when social and economical development of certain regions is uneven, traditional forms and methods of economical development support which haven't provided positive result in more favorable period, have no chance to success. All the more so as they will be very difficult to implement at risk of mid-term destabilization of the Russian economy and budget stability due to geopolitical tension resulting from the events involving Ukraine and in circumstances where investments and economical activity at large continue to decline.

\section{Conclusions}

Therefore, a radically new mechanism of regions' economical growth is required. At this, the main directions in eliminating imbalance of Russian regions' economic development should be the following:

- a deliberate national federal and regional policy targeted at searching out new (original) sources of economical growth at their territory;

- formation of favorable competitive environment in the region through creating new industrial clusters in the 
framework of the import substitution policy;

- development of primary industry in accordance with natural, climatic and resource conditions in Russian regions;

- economically justified use of government support tools for development of small and medium enterprises in primary industry, including food processing industry which can be given renewed momentum for development in the context of food embargo;

- establishment of mutually profitable economic contacts with potential participants of commercial intercourse in other regions of the country (including new ones) and foreign partners.

Also, the regional strategies should include measures for monitoring their social and economical development, define targets of government support of priority industrial sectors, and propose amount of finance and other sources of development.

\section{References}

Anderson Ph., Anderson C. S., Velandia-Rubiano A. Public Debt Management in Emerging Market Economies: Has This Time Been Different? / World Bank Policy Research Working Paper. 2010. No. WPS 5399. - 28p.

Barro R. The Ricardian Approach to Budget Deficits // Journal of Economic Perspectives, 1989, № 2, P. 37-54.

Checherita C. and Rother P. The Impact of High and Growing Government Debt on Economic Growth An Empirical Investigation for the Euro Area // European Central Bank WP, 2010, № 1237, P. 1-40.

Cochrane J. Understanding policy in the great recession: Some unpleasant fiscal arithmetic // European Economic Review, 2011, № 55(1), P. 2-30.

Gale W., Orszag P. The Economic Effects of Long-term Fiscal Discipline // Urban-Brookings Tax Policy Center Discussion Paper, 2003, № 8, P. 1-30.

Groneck M. A golden rule of public finance or a fixed deficit regime?: Growth and welfare effects of budget rules // Economic Modelling, 2010, Vol. 27, № 2, P. 523-534.

Elmendorf D., Mankiw G. Government debt.: Handbook of Macroeconomics, 1999. - 82p.

Hanson J. The growth in government domestic debt: changing burdens and risks // Policy Research WP Series, 2007, № 4348, P. 1-38.

Keynes J. The General Theory of Employment, Interest and Money. - L.: Macmillan Cambridge University Press, 1936. - 352p.

Kutivadze N. Public debt, domestic and external financing, and economic growth // Departmental WP, 2012, № 12, P. 1-35.

Modigliani F. Long-run implications of alternative fiscal policies and the burden of the national debt // Economic Journal, 1961, № 71, P. 730-755.

Moore W., Chrystol T. A meta-analysis of the relationship between debt and growth // Munich Personal RePEc Archive Paper, 2008, № 21474, P. 1-23.

Siti N., Mohd D., Podivinsky J. Revisiting the role of external debt in economic growth of developing countries // Journal of Business Economics and Management, 2013 P. 968-993.

Sutherland D., Hoeller P. Debt and Macroeconomic Stability: An Overview of the Literature and Some Empirics // OECD Economics Department WP, 2012, № 1006, P.1-35.

Schclarek A. Debt and economic growth in developing and industrial countries // Lund University Working Papers, 2005, № 34, P. 1-39. 